\title{
Economics
}

\section{Appraisal of Human Resource Accounting on Profitability of Corporate Organization}

\author{
Ezejiofor Raymond Asika ${ }^{1}$, John-Akamelu Racheal Chitom ${ }^{2}$, Iyidiobi Felicia Chelichi \\ ${ }^{1}$ Department of Accountancy, Faculty of Management Sciences, Nnamdi Azikiwe University, Awka, Nigeria \\ ${ }^{2}$ Department of Entrepreneur Studies Unit, Faculty of Management Sciences, Nnamdi Azikiwe University, Awka, Nigeria \\ ${ }^{3}$ Department of Accountancy, Faculty of Business Studies, Enugu State University of Science and Technology, Enugu, Nigeria
}

Email address:

thaddray4life@yahoo.com (Ezejiofor R. A.), rachealchitom@gmail.com (John-Akamelu R. C.), iyidiobi@Esult.edu.ng (Iyidiobi F. C.)

\section{To cite this article:}

Ezejiofor Raymond Asika, John-Akamelu Racheal Chitom, Iyidiobi Felicia Chelichi. Appraisal of Human Resource Accounting on Profitability of Corporate Organization. Economics. Vol. 6, No. 1, 2017, pp. 1-10. doi: 10.11648/j.eco.20170601.11

Received: February 11, 2017; Accepted: February 22, 2017; Published: March 28, 2017

\begin{abstract}
This study is to determine the adoption of Human Resource Accounting (increase in staff salary, increment in staff and staff retirement benefits) on the Profitability of Corporate Organizations. Specifically, the study sought; to determine the extent at which increase in staff salary has affected organizational profitability; to ascertain if the increment in staff has contributed positively on organizational profitability and to evaluate the extent at which staff retirement benefits has effect on organizational profitability. Research questions and hypotheses were formulated in line with the objectives of the study. Exploratory research design and time series data were adopted for this study. Data for the study were collected from selected ten (10) commercial banks in Nigeria. Data collected were analyzed and tested with t-test statistical tool with aid of SPSS version 20.0 version. The study revealed that the study revealed that increase in staff salary has positive effect on organizational profitability, also that the level of increment in staff has influence on organizational profitability. Another finding is that staff retirement benefits have positive effect on organizational profitability. The study recommends among other things that the relevant authorities should look into coming up with a financial reporting standard on human resource activities. Also that organization should enhance the retention of education and training on staff so as to avert wastage of knowledgeable investment.
\end{abstract}

Keywords: Human Resource Accounting, Corporate Organization, Commercial Banks, Profitability and Staff Welfare

\section{Introduction}

Human Resource accounting has been the focus of much academic research since the late 1960's. Human Resource is a term which refers to the set of individuals who make up the workforce of an organization or a business entity. This may be attributed to the apparent increasing recognition within the business community of the importance major stakeholders attach to socially and environmentally responsible corporate behavior (Enofe, Mgbame \& Ovie, 2013).

Human resource accounting (HRA) is of topical origin and is struggling for acceptance. It is clearly said that, Human resources accounting is an accounting measurement system and a large body of literature has been published in the last decade setting for the various procedures for measurement. At the same time the theory and underlying concepts of accounting measurement have received generous attention from academicians and a substantial body of literature has been developed. Under conventional accounting system, human resources are not recognized as physical or financial assets (Mustafizur, Amzad \& Tabassum, 2013).

The application of HRA varies across organizations and countries (Boedker, Mouritsen \& Guthrie, 2008). Some organizations adopt a valuation method suitable for the measurement of their human resources and report such information as additional information or provide supplementary statements in the annual reports. Swedish companies measure and report some of their intangibles such as human resources and intellectual capital according to Swedish models. Large Finnish Companies provide information on training and staff development in their corporate annual reports. United Kingdom through a business committee of practice referred to as MARIA (Managing and 
Reporting Intangible Assets) identify; value and report on their intangibles. India is one of the countries noted for HRA. Literature provides that a number of entities in both the public and private sectors of the country, takes interest in monetary valuation of their human resources (Pandey, 2014 \& Orjha, 2013).

Abdullahi and Kirfi (2012) maintain that the quantification of the value of Human Resources helps the management to cope up with the changes in its quantum and quality so that equilibrium can be achieved in-between the required resources and the provided human resources. As a result, it becomes imperative to put measures in place to effectively manage people with their needs and expectations to enhance productivity. Therefore, proper appreciation of human resource accounting will enable managers take appropriate decisions regarding investment in human resources.

Though Human Resources Accounting was introduced back in the 1980s, it started gaining popularity in India after it was adopted and popularized by NLC. Human Resources accounting, also known as Human Asset Accounting, is an information system involved in identifying, measuring, capturing, tracking and analyzing the potential of the human resources of a company and communicating the resultant information to the stakeholders of the company. It is a method by which a cost is assigned to every employee when recruited, and the value that the employee would generate in the future. Human Resource accounting reflected the potential of the human resources of an organization in monetary terms, in its financial statements (Mustafizur, Amzad \& Tabassum, 2013).

Back in mid of 1980's, behavioral scientists criticized the conventional accounting system for its failure to value the human resources of the organization. In this changing perspective the accountants were also called upon to play their role by assigning monetary value to the human resources deployed in the organization. Furthermore, the sturdy growth of international financial reporting standards (IFRS) is another indication that the environment for financial accounting reporting is one that potentially encourages the consideration of alternative measurement and reporting standards.

Many authors and scholars have conducted researches on how humans within an organization can be valued and reported in the financial statements of such organization (Schulz, 1961; Likert, 1967; Bowers, 1973; Flamholz, Bullen \& Hua, 2002). Human resource accounting and reporting by corporate organizations is still at the infant stage in Nigeria. Some of the companies that have invested heavily in human resources and have applied human resources accounting in one way or the other in Nigeria include both banking sector, manufacturing sector, oil and gas sector amongst others. The investments by these companies in human capital development are normally not reflected in their balance sheets as assets but expensed in the profit and loss accounts (Okapla \& Chidi, 2010; Micah, Ofurun \& Ihendinihu, 2012). The major challenges encountered in the recognition of human resources as an asset rest largely on its characteristics, quantification in monetary terms and the method of reporting.

The work of Bassey and Tapang (2012) points to the fact that human resources have been identified as one of the main sources of competitive advantage by many organizations in today's economy. Particularly, the private sector organizations are widely diverse and have focused on human resources as having special strategic value for organization development.

Singh and Singh, (2009), Sir William Petty (1623-1687) made the first attempt to value human beings in monetary terms by treating human being in an organization as an element of Wealth. From the above development, the study set out to appraise the adoption human resource accounting on profitability of Nigerian firms.

\subsection{Objectives of the Study}

The main objective of this study is to determine the adoption of Human Resource Accounting (increase in staff salary, increment in staff and staff retirement benefits) on the Profitability of Corporate Organizations. Specifically, the study sought;

1. To determine the extent at which increase in staff salary has affected organizational profitability.

2. To ascertain if the increment in staff has contributed positively on organizational profitability.

3. To evaluate the extent at which staff retirement benefits has effect on organizational profitability.

\subsection{Formulation of Hypotheses}

1. $\mathrm{H}_{\mathrm{I}}$ : Increase in staff salary has positive effect on organizational profitability.

$\mathrm{H}_{\mathrm{O}}$ : Increase in staff salary has no positive effect on organizational profitability.

2. $\mathrm{H}_{\mathrm{I}}$ : The level of increment in staff has influence on organizational profitability.

$\mathrm{H}_{\mathrm{O}}$ : The level of increment in staff does not have any influence on organizational profitability.

3. $\mathrm{H}_{\mathrm{I}}$ : Staff retirement benefits have positive effect on organizational profitability.

$\mathrm{H}_{\mathrm{O}}$ : Staff retirement benefits do not have positive effect on the organizational profitability.

\section{Review of Related Literature}

\subsection{Conceptual Framework}

1. The Concept of Human Resource Accounting (HRA)

In economics we find the major factors of production are the land, labor, capital and entrepreneur. Every organization reports on and includes land and capital in its financial statements, but labor and entrepreneur are not given much attention and hence, they only represent a charge against the profit made by the organization (Abubakar, 2006; Glautier, 1974). The two factors, labor and entrepreneur, are the human assets or resources organizations have.

Jasrotia (2004), in her definition, also views HRA as a 
measurement and reporting of the cost and value of people as organizational resources. The uniqueness of this definition is on the reporting aspect of the HRA. This definition rests on the premise that knowledge and intellectual capabilities of employees are becoming more and more important in corporate investment decision-making. This is because of the fact that service industries are now overtaking the manufacturing industries and in service providing business, the knowledge and intellectual competences of employees matter more than any other tangible asset.

Human Resource Accounting (HRA) is the process of identifying, recording and reporting the Investments made in the Human Resources of an Organization that are presently not accounted for in the conventional accounting practices. In other words, it is an extension of the existing "Expense recognition principle" or "Matching Principles" that requires revenue to be matched with expenses incurred to earn that amount of revenue and of organizing data to communicate relevant information. This effort to quantify the value of Human Resources helps the management to cope up with the changes in its quantum and quality so that equilibrium can be achieved in between the required resources and the benefit derived from such resources.

The American Accounting Association (1973) defined Human Resource Accounting as the process of identifying, measuring and communicating information about human resources in order to facilitate effective management within an organization. Human capital can be defined as the knowledge that individuals acquire during their lifetimes and use to produce goods, services or ideas in market or nonmarket circumstances. This definition considers HRA as the process of recognition and the quantification of human resources for the purpose of assisting the effective management of an organization. The definition is however unfinished as it is not specific as to what constitute the human resources expenditure and how it is to be recognized.

Friedman and Lev (1974) and Lau and Lau (1978) consider HRA as a method for systematically measuring both the asset value of labor and the amount of asset creation that can be attributed to personnel activities. Considering the contribution aspect of human resources this definition incorporates the economic benefit attributable to the human resources in addition to recognizing their cost implication.

\section{Importance of Human Resource Accounting}

HRA is not useful to the management solitarily in achieving its economic goals. It could also be the source of important information for investment decision purposes. The inclusion of appropriate human resource information in published financial statements would, in all likelihood, make such statements for more meaningful in predicting future performance which is, of course, the principal concern of investors (Jawahar Lal, 2009).

Sveiby (1997) argued that organizations acquire Human Resources to generate future revenues, and therefore Human Resource should be considered when valuing a company by capitalizing instead of expensing them in the current period. According to him human capital, intellectual capital and structural capital concepts are similar to other assets. Human resources is largely seen as an integral part of the firm's value - creating processes (Holland, 2003;) as well as creating and maintaining competitive advantage (Holland, 2006).

In today's dynamic business environment, firms invest heavily in human capital assets. The problem however, is that these investments are either immediately expensed in the financial statement or arbitrarily amortized and therefore are not fully reflected in the balance sheet. Consequently, the book values of firms with significant amounts of human capital investments are unrelated to the market values (Amir and Lev, 1996; Brennan, 2001; Lev, 2001; Holland, 2003).

From the point of advertisement for a particular post to the point of departure, organizations do commit some financial resources to the employee. Many reasons culminated into the spending nature of organizations on their human resources. Abubakar (2006) identifies that getting the best human brain, achieving the pre-determined objectives of the organization, Commanding Respect in the Eyes of Stakeholders, gaining Competitive Advantage, Becoming the Pace Setter and Market Leader are some of the reasons why organizations do invest a lot of financial resources on their human capital.

However, Roslender and Fincham (2001), and also revealed areas through which organizations invest money relative to their human resources. The identified areas are Advertisement, Recruitment and Selection, Familiarization and Training, Training and Development, Medical and Entertainment.

\section{Human Capital}

The concept of human capital is the basis for human resources accounting. This concept, at the enterprise level is not of recent origin. Investment in human capital was considered in the writing of Adam Smith (Brument et al, 1970). Many other economists and social scientists have sought to understand the nature and casual aspects of industrial growth. The contribution of human factor to this growth had generated great interest among researchers (Tailor \& Glautier, 1974).

Likert (1967) drew attention to human resource accounting which is also called human asset accounting, particularly by personnel and behavioral experts. Identification of Human Resources Human resources accounting has been defined as "the process of identifying and measuring data about human resources, and communicating this information to interested parties (Carper, 2002). The three major components involved in this definition include:

(1) Identification of human resources as assets;

(2) Measurement of asset data about human resources; and

(3) Communication of this information to interested parties.

The issue of whether employees of an entity constitute an asset, and the possible attributes of individuals to be valued, has been at the centre of discussion on human resources accounting. Historically, accountants have viewed assets from diverse standpoints, some of which are: Things of value owned, Deferred charges, A combination of the two and economic view. 


\section{Methods of Accounting for Human Asset}

According to Obara (2013), the major objective of human asset accounting is to clarify the gap between the market and the book value of an enterprise. In doing this, the contribution of a vital factor (personnel) is evaluated. Gebauer (2003), stressed that the procedures can be classified on the basis of two distinctive features-first, the evaluation objects and, second the dimensions of the result. As regards the evaluation object, some methods target the evaluation of individuals; other methods are aligned to observing the evaluation by means of groups. The second distinctive feature that is the dimensions of the result, deals with the determination of monetary and non-monetary values for human capital. The non-monetary methods are directed at the determination of percentage numbers or at a number on a specifically crated scale. The monetary methods on the other hand can be differentiated in cost and value-based methods (Sackman, 1989).

\section{Profitability}

Profitability means ability to make profit from all the business activities of an organization, company, firm, or an enterprise. It shows how efficiently the management can make profit by using all the resources available in the market.

According to Harward and Upton (2012), profitability is the "the ability of a given investment to earn a return from its use. However, the term 'Profitability' is not synonymous to the term 'Efficiency'. Profitability is an index of efficiency; and is regarded as a measure of efficiency and management guide to greater efficiency. Though, profitability is an important yardstick for measuring the efficiency, the extent of profitability cannot be taken as a final proof of efficiency. Sometimes satisfactory profits can mark inefficiency and conversely, a proper degree of efficiency can be accompanied by an absence of profit. The net profit figure simply reveals a satisfactory balance between the values receive and value given. The change in operational efficiency is merely one of the factors on which profitability of an enterprise largely depends. Moreover, there are many other factors besides efficiency, which affect the profitability.

6. Human Asset Treatment and Corporate Profitability

The main problem confronting human asset treatment in organizations include the difficulty to measure or value human capital over the last two decades, which has ran into the difficult problem of pricing such assets (Strassman, 1998). But the benefit associated with the exercise has forced many companies to embark on the exercise. Research carried out by Leadbeater and Demos (1999) in the UK revealed that methods used to measure human assets depend on which user group the report is for (Leadbeater \& Demos, 1999). They stressed that internal users such as managers prefer the treatments that allow for more information and which allow human asset to be managed more effectively. For such users, a new range of performance measurement and internal corporate reporting which attempts to link financial performance such as cash flow to intangible drivers are sufficient. Examples include: Economic Value Added (EVA) and European Foundation for Quality Model (EFQM). There is another approach as recommended and used by ten Danish and Swedish companies in their HAAT which is capable to show the underlying fundamental that determines a company's future growth and the link between human with the strategies of the companies. In Nigeria, the companies do not have any standard approach to measure or treat human assets in their organizations (Obara, 2013).

The traditional human asset accounting theories also identified three major areas of cost items of human asset investments (Flamholtz, 1973). It therefore means companies could identify those items and separate them from their profit and loss accounts; such treatments would definitely impact on the corporate portability of the firm. The extents to which an organization can practice human asset accounting treatments have strong relationship with its profitability.

\subsection{Empirical Studies}

A number of empirical studies have been conducted on the issue of human resource accounting in corporate organizations. A number of these studies have highlighted the need to capitalize human capital asset in the balance sheet of companies as against being written off as expenses in the profit and loss accounts (Enofe, Sunday \& Ovie, 2013).

Shaghayegh, Somayeh, Elham and Beheshteh (2013) identify the main factors of implementing human resource development in the Iranian Social Security Organization's Hospitals. This study was descriptive and applicable. Sixty five Iranian Social Security Organization Hospitals (the major governmental health institutions in Iran) were chosen as a sample among all Iranian healthcare centers.

The members of research community were educational managements and educational experts of these hospitals $(n=130)$. To achieve this objective, a questionnaire was designed for reviewing the current state of human resource development. Content validity and construct validity were assured with expert judgment and the reliability of the questionnaire was determined using Cronbach's alpha and Pearson correlation (first and second times). After the sample size was shown to be sufficient, the exploratory and confirmatory of factors were analyzed. The findings of the present study showed that one factor with seven variables was extracted, respectively the calculated fitness indices emphasized the desirable fitness. Then this factor was named "action of HRD". It can be concluded that this factor and its variables has a main role in implementing human resource development and are considered to be the main factor while implementing human resource development in these organizations.

Hermannson (1964), in his pioneer work concerning the valuation of human assets attempts to place money value on human capital in the balance sheet.

Barney (1991), notes that human resources accounting has helped in solving most personnel related problems in corporate organizations. Barney (1991), further asserts that sustainable competitive advantage is attained when the firm has human resource pool that cannot be imitated or substituted by its rivals. 
Syed (2009), examined the relationship between corporate characteristics and human resource accounting disclosure and concluded that companies with higher profitability intended to disclose more human resource accounting information.

There have been also been some empirical researches on the issues of human resource accounting in Nigeria.

Okpala and Chidi (2010) in their work, examined the relevance of human capital accounting to stock investment decisions in Nigeria and opine that corporate success now rests on the ability and knowledge of people who can easily adapt to technological changes and drive organization to attain its goals and objectives. They explain that the function of human capital accounting is to provide information which affords investors opportunity to truly evaluate and understand the complete picture of an organization.

Kirfi and Abdullahi (2012), view the practice of human resources accounting in Nigerian companies as more of a mirage than reality as human resource is not reported in financial statements. Kirfi and Abdullahi (2012), argue that the existing accounting practice lack regard to human resource as an asset and have significantly discouraged the use of any or a combination of measurement technique(s) in quantifying human resource let alone reporting it in Nigeria.

Bassey and Tarpang (2012), examined the influence of expensed human resources cost (HRC) on corporate productivity and found that expensed human resources (remuneration, protection and dismissal/ compensation) costs are important determinants of expensed human resources cost and does significantly influence corporate productivity.

Likert (1967), stressed that short-term company profits are too often obtained through automatic "system I" methods, which result in the wastage of human resources through neglect of training and development, turnover, reduced cooperation, etc. His argument was that conventional accounting procedures ignore human assets, even though their depletion almost inevitably leads to reductions in profit over the long run. He challenged the accountants to develop measures for valuing the human resources so that changes could be recorded on the scorecard that counts, the profit or loss statement.

In response to Likert (1967), challenges, many accountants conducted researches on how best to measure human resources in monetary terms. Prominent among them are Flamholtz (1999) and Lev and Schwartz (1974). Their contributions led to the suggestion of various methods of valuing human resources such as replacement cost model, stochastic rewards valuation model, historical cost model, competitive bidding method, and capitalization of future benefit. Strauss (1976) cautioned that numerous conceptual and practical problems must be solved before human resource accounting is widely accepted. These problems, according to him, relate particularly to the method of calculating human resource values and to the use to which the resulting data will be put such as its impact on managerial or investor behavior.

\subsection{Summary of Literature}

Many authors and scholars have conducted researches on how humans within an organization can be valued and reported in the financial statements of such organization. (Schulz, 1961; Hermannson, 1964; Likert, 1967; Bowers, 1973; Flamholz, Bullen \& Hua, 2002). Human resource accounting and reporting by corporate organizations is still at the infant stage in Nigeria. Some of the companies that have invested heavily in human resources and have applied human resources accounting in one way or the other in Nigeria include both banking sector, manufacturing sector, oil and gas sector amongst others. Edom, inah and Eyisi (2015) revealed that there is a positive relationship between the indicators of human resource cost (training cost, development cost and number of staff) and the profit of the organization, Onyekwelu, Osisioma and Ugwuanyi (2015) reveals among others that there is a significant increase in firms' net worth when investments on human capital are treated as assets. Ogenyi and Oladele (2015) showed that asset recognition criteria and disclosure requirements were highly responsible for the non-accounting for Human Resources in Nigeria even on a voluntary basis. Enofe, Mgbame, Otuya and Ovie (2013) find that a positive relationship exists between the financial performance of a company and its level of Human Resource Accounting Disclosure. However, the major challenges encountered in the recognition of human resources as an asset rest largely on its characteristics, quantification in monetary terms and how. This can affect human capacity and productivities in an organization. This study therefore set out to evaluate the impact of human resource accounting on the performance of Nigerian banking industry.

\section{Methodology}

\subsection{Research Design}

Research design involves collection of data in other to found answers to unanswered questions at a particular period concerning the current status of a subject. Due to the nature of this study, ex-post facto research design and time series data were adopted for this study.

The population of this study consists of sixteen (16) commercial banks quoted on the Nigerian stock exchange. These commercial banks are stated in the table below;

The researcher used simple sampling technique to select ten (10) commercial banks in Nigeria for the study. These banks were chosen based on the fact that there was availability of data that was relevant to this study. These ten banks were presented in table 1 below:

Table 1. The sample Size for the study.

\begin{tabular}{ll}
\hline S/N & Banks \\
\hline 1 & Access bank plc \\
2 & Diamond bank plc \\
3 & First bank plc \\
4 & FCMB plc \\
5 & GTB plc \\
6 & Zenith bank plc \\
7 & Sterling bank plc \\
8 & UBA plc \\
9 & Fidelity bank plc \\
10 & Wema bank plc \\
\hline
\end{tabular}




\subsection{Method of Data Analysis}

The variables considered in this study are increase in staff salary, increment in staff and staff retirement benefits as independent variables; while profitability is the dependent variable.

In analysis of the data collected, five years annual accounts and report of the ten selected commercial banks were used and tested with paired t-test. This was done with aid of the
Statistical Package for Social Sciences (SPSS) was used at 95\% confidence at five degree of freedom (df).

Decision Rule

The decision rule is by comparing the t-value with sigvalue with $5 \%$ level of significance. If the t-value is greater of equal to sig-value, we accept alternative hypothesis and reject null hypothesis, otherwise we reject alternative hypothesis and accept null hypothesis.

\section{Data Presentation, Analysis and Interpretation}

\subsection{Data Presentation}

Table 2. Profit before tax of commercial banks.

\begin{tabular}{|c|c|c|c|c|c|c|}
\hline $\mathbf{S} / \mathbf{N}$ & Banks & $2014^{\prime} 000$ & $2013 ’ 000$ & $2012^{\prime} 000$ & $2011^{\prime} 000$ & $2010 ’ 000$ \\
\hline 1 & Access bank plc & $46,142,422$ & $31,365,396$ & $36,259,530$ & $12,141,462$ & $17,668,584$ \\
\hline 2 & Diamond bank plc & 24413014 & 33250472 & 28364965 & -27132209 & $9,468,016$ \\
\hline 3 & First bank plc & $5,683,000$ & $70,631,000$ & $92,701,000$ & $35,863,000$ & $31,491,000$ \\
\hline 5 & GTB plc & $116,385,843$ & $107,091,256$ & $103,027,923$ & $62,080,206$ & $46,275,192$ \\
\hline 6 & Zenith bank plc & $108,290,000$ & $94,108,000$ & $94,048,000$ & $57,144,000$ & $50,114,000$ \\
\hline 7 & Sterling bank plc & $10,747,985$ & $9,310,198$ & $7,499,651$ & $5,640,306$ & $3,688,251$ \\
\hline 9 & Fidelity bank plc & $13,389,000$ & $13,659,000$ & $21,349,000$ & $1,474,000$ & $8,325,000$ \\
\hline \multirow[t]{2}{*}{10} & Wema bank plc & $3,093,940$ & $1,947,308$ & $-4,942,211$ & $-3,770,021$ & $12,964,108$ \\
\hline & Total & $370,523,204$ & $424,221,773$ & $440,735,877$ & $132,316,941$ & $146,239,151$ \\
\hline
\end{tabular}

Table 3. Staff salary.

\begin{tabular}{|c|c|c|c|c|c|c|}
\hline $\mathbf{s} / \mathbf{n}$ & Banks & $2014 ’ 000$ & 2013'000 & $2012^{\prime} 000$ & $2011^{\prime} 000$ & $2010 ’ 000$ \\
\hline 1 & Access bank plc & $24,441,936$ & $24,596,464$ & $21,726,358$ & $11,433,865$ & $11,245,365$ \\
\hline 2 & Diamond bank plc & 7170669 & 22755279 & 18544500 & 14165618 & $13,028,071$ \\
\hline 3 & First bank plc & $1,147,000$ & $50,000,000$ & $47,916,000$ & $48,655,000$ & $38,324,000$ \\
\hline 4 & FCMB plc & $23,427,447$ & $20,729,426$ & $14,445,011$ & $11,683,364$ & $11,955,741$ \\
\hline 5 & GTB plc & $20,707,517$ & $19,055,211$ & $18,197,947$ & $18,319,173$ & $16,926,320$ \\
\hline 6 & Zenith bank plc & $67,311,000$ & $59,952,000$ & $42,410,000$ & $29,189,000$ & $39,559,000$ \\
\hline 7 & Sterling bank plc & $11,426,659$ & $9,841,203$ & $8,778,263$ & $6,188,369$ & $6,004,845$ \\
\hline 9 & Fidelity bank plc & $27,051,000$ & $24,231,000$ & $21,780,000$ & $13,987,000$ & $11,679,000$ \\
\hline \multirow[t]{2}{*}{10} & Wema bank plc & $8,862,297$ & $7,531,760$ & $5,585,339$ & $5,903,742$ & $6,771,111$ \\
\hline & Total & $232,344,525$ & $275,571,343$ & $228,278,418$ & $184,232,131$ & $182,152,453$ \\
\hline
\end{tabular}

Table 4. Number of staff.

\begin{tabular}{|c|c|c|c|c|c|c|}
\hline$S / n$ & Banks & $2014 ’ 000$ & $2013^{\prime} 000$ & $2012^{\prime} 000$ & $2011^{\prime} 000$ & $2010 ’ 000$ \\
\hline 1 & Access bank plc & 2,721 & 2,461 & 2,896 & 1,257 & 1,317 \\
\hline 2 & Diamond bank plc & 4,568 & 3,805 & 2912 & 2685 & 2,625 \\
\hline 3 & First bank plc & - & - & - & - & 7,598 \\
\hline 4 & Fcmb plc & 4,430 & 4,202 & 3,023 & 1,779 & 2,030 \\
\hline 5 & Gtb plc & 3,340 & 3,155 & 2,920 & 2,908 & 2,700 \\
\hline 6 & Zenith bank plc & 7,089 & 6,615 & 7,164 & 7,184 & 7,386 \\
\hline 7 & Sterling bank plc & 3,042 & 2,735 & 2,672 & 1,908 & 1,611 \\
\hline 9 & Fidelity bank plc & - & 3,490 & 3,491 & 3,504 & 3,201 \\
\hline \multirow[t]{2}{*}{10} & Wema bank plc & - & - & 1,341 & 1,349 & 1,832 \\
\hline & Total & 35,183 & 36,766 & 35,454 & 32,418 & 40,942 \\
\hline
\end{tabular}

Table 5. Retirement benefits

\begin{tabular}{lllllll}
\hline s/n & Banks & $\mathbf{2 0 1 4}$ '000 & 2013'000 & 2012'000 & 2011'000 \\
\hline 1 & Access bank plc & 565,204 & 427,402 & $1,152,061$ & $1,068,780$ \\
2 & Diamond bank plc & $4,867,504$ & $3,311,616$ & $1,813,224$ & 473632 \\
3 & First bank plc & $1,159,000$ & 58,000 & 19,380 & 14,718 \\
4 & FCMB plc & 300,928 & 70,329 & 631,418 & $1,603,094$ \\
5 & GTB plc & 688,740 & 687,412 & 708,316 & 27,149 & 6413,755 \\
\hline
\end{tabular}




\begin{tabular}{|c|c|c|c|c|c|c|}
\hline $\mathbf{s} / \mathbf{n}$ & Banks & $2014 ’ 000$ & $2013 ’ 000$ & $2012^{\prime} 000$ & 2011'000 & $2010 ’ 000$ \\
\hline 6 & Zenith bank plc & $1,350,000$ & $1,172,000$ & $2,841,000$ & $2,239,000$ & $2,239,000$ \\
\hline 7 & Sterling bank plc & 604,367 & 425,420 & 614,314 & 379,289 & 496,215 \\
\hline 8 & UBA plc & $1,283,000$ & $-1,108,000$ & $-850,000$ & $2,009,000$ & $1,798,000$ \\
\hline 9 & Fidelity bank plc & & 967,000 & 434,000 & 661,000 & 786,000 \\
\hline \multirow[t]{2}{*}{10} & Wema bank plc & 611,616 & 675,732 & 609,494 & 652,662 & 593,273 \\
\hline & Total & $11,430,359$ & $6,686,911$ & $7,973,207$ & $9,555,390$ & $8,854,349$ \\
\hline
\end{tabular}

\subsection{Test of Hypotheses}

Hypothesis One

$\mathrm{H}_{\mathrm{I}}$ : Increase in staff salary has positive effect on organizational profitability.

$\mathrm{H}_{\mathrm{O}}$ : Increase in staff salary has no positive effect on organizational profitability.

Table 6. Paired Sample Statistics for Hypothesis one.

\begin{tabular}{llllll}
\hline \multicolumn{2}{l}{ Paired Samples Statistics } & & & & \\
\hline & & Mean & N & Std. Deviation & Std. Error Mean \\
\hline \multirow{2}{*}{ Pair 1} & Profitability & 302807389.20 & 5 & 151601251.689 & 67798140.850 \\
& Staffsalary & 220515774.00 & 5 & 38792849.913 & 17348689.889 \\
\hline
\end{tabular}

Table 7. Paired Sample t-Test for Hypothesis one.

\begin{tabular}{|c|c|c|c|c|c|c|c|c|c|}
\hline \multicolumn{10}{|c|}{ Paired Samples Test } \\
\hline & & \multicolumn{5}{|c|}{ Paired Differences } & \multirow{3}{*}{$\mathbf{T}$} & \multirow{3}{*}{ df } & \multirow{3}{*}{ Sig. (2-tailed) } \\
\hline & & \multirow{2}{*}{ Mean } & \multirow{2}{*}{ Std. Deviation } & \multirow{2}{*}{ Std. Error Mean } & \multicolumn{2}{|c|}{ 95\% Confidence Interval of the Difference } & & & \\
\hline & & & & & Lower & Upper & & & \\
\hline Pair 1 & $\begin{array}{l}\text { Profitability } \\
- \\
\text { Staffsalary }\end{array}$ & 82291615.2 & 118800118.0 & 53129027.9 & -65218214.3 & 229801444.6 & 1.549 & 4 & .196 \\
\hline
\end{tabular}

From the table above, the paired mean difference of profitability-staff salary is positive and significant at (.196) with a $t$ value of (1.549). Therefore, we reject null hypothesis and accept alternative hypothesis which uphold that Increase in staff salary has positive effect on organizational profitability.

Table 8. Paired Sample Statistics for Hypothesis two.

\begin{tabular}{|c|c|c|c|c|c|}
\hline \multicolumn{6}{|c|}{ Paired Samples Statistics } \\
\hline & & Mean & $\mathbf{N}$ & Std. Deviation & Std. Error Mean \\
\hline \multirow{2}{*}{ Pair 1} & Profitability & 302807389.20 & 5 & 151601251.689 & 67798140.850 \\
\hline & Staff number & 36152.60 & 5 & 3110.065 & 1390.863 \\
\hline
\end{tabular}

Table 9. Paired Sample t-test for Hypothesis two.

\begin{tabular}{|c|c|c|c|c|c|c|c|c|c|}
\hline \multicolumn{10}{|c|}{ Paired Samples Test } \\
\hline & & \multicolumn{5}{|c|}{ Paired Differences } & \multirow{3}{*}{$\mathbf{T}$} & \multirow{3}{*}{ df } & \multirow{3}{*}{ Sig. (2-tailed) } \\
\hline & & \multirow{2}{*}{ Mean } & \multirow{2}{*}{ Std. Deviation } & \multirow{2}{*}{ Std. Error Mean } & \multicolumn{2}{|c|}{ 95\% Confidence Interval of the Difference } & & & \\
\hline & & & & & Lower & Upper & & & \\
\hline Pair 1 & $\begin{array}{l}\text { Profitability - } \\
\text { Staffnumber }\end{array}$ & 302771236.6 & 151601582.7 & 67798288.9 & 114533009.3 & 491009463.9 & 4.466 & 4 & .011 \\
\hline
\end{tabular}

From the table above, the paired mean difference of Profitability-staff number is positive and significant at (.011) with a $t$ value of (4.466). Therefore, we reject null hypothesis and accept alternative hypothesis which uphold that the level of increment in staff has influence on organizational profitability.

Table 10. Paired Sample Statistics for Hypothesis three.
Hypothesis Two

$\mathrm{H}_{\mathrm{I}}$ : The level of increment in staff has influence on organizational profitability.

$\mathrm{H}_{\mathrm{O}}$ : The level of increment in staff does not have any influence on organizational profitability.

\begin{tabular}{|c|c|c|c|c|c|}
\hline \multicolumn{6}{|c|}{ Paired Samples Statistics } \\
\hline & & Mean & $\mathbf{N}$ & Std. Deviation & Std. Error Mean \\
\hline \multirow{2}{*}{ Pair 1} & Profitability & 302807389.20 & 5 & 151601251.689 & 67798140.850 \\
\hline & Staffbenefits & 8900043.20 & 5 & 1774193.120 & 793443.284 \\
\hline
\end{tabular}


Table 11. Paired Sample t-test for Hypothesis three.

\begin{tabular}{|c|c|c|c|c|c|c|c|c|c|}
\hline \multicolumn{10}{|c|}{ Paired Samples Test } \\
\hline & & \multicolumn{5}{|c|}{ Paired Differences } & \multirow{3}{*}{$\mathrm{t}$} & \multirow{3}{*}{ df } & \multirow{3}{*}{ Sig. (2-tailed) } \\
\hline & & \multirow{2}{*}{ Mean } & \multirow{2}{*}{ Std. Deviation } & \multirow{2}{*}{ Std. Error Mean } & \multicolumn{2}{|c|}{ 95\% Confidence Interval of the Difference } & & & \\
\hline & & & & & Lower & Upper & & & \\
\hline Pair 1 & $\begin{array}{l}\text { Profitability - } \\
\text { Staffbenefits }\end{array}$ & 293907346.0 & 152154446.96 & 68045537.30 & 104982647.04 & 482832044.96 & 4.319 & 4 & .012 \\
\hline
\end{tabular}

From the table above, the paired mean difference of Profitability-staff benefits is positive and significant at (.012) with a $t$ value of (4.319). Therefore, we reject null hypothesis and accept alternative hypothesis which uphold that staff retirement benefits have positive effect on organizational profitability.

Based on the empirical analysis, the t-test results showed that the variables tested have positive signs. The implication of these results are that increase in staff salary, increment in staff and staff retirement benefits are all positively related to the profitability of the banks for the period of study. This means an increase in training cost, development cost and number of staff could lead to increase in profitability of the Banks. This confirm to economic criterion, and could be supported by the works of Enofe, Sunday, \& Ovie (2013), they opined that the greatest assets are the employees. This indicates that profit level does not depend on the rate of its employees rather other assets. Also, Edom, inah and Eyisi (2015) revealed that there is a positive relationship between the indicators of human resource cost (training cost, development cost and number of staff) and the profit of the organization.

\section{Summary of Findings, Conclusion and Recommendations}

\subsection{Summary of Findings}

Based on the outcome from the analysis, the following summary of findings were stated;

1. The study revealed that increase in staff salary has positive effect on organizational profitability.

2. Also that the level of increment in staff has influence on organizational profitability.

3. Another finding is that staff retirement benefits have positive effect on organizational profitability.

\subsection{Conclusion}

This study was carried out to determine the effect of adoption of human resource accounting on the profitability of corporate organizations. An overall test was carried out to observe that there is a significant effect on all independent variable (increase in staff salary, increment in staff and staff retirement benefits) on the dependent variable (profitability). In line with this, it is justified that three independent variables have a proportionate impact in predicting the profitability of the firm. It is therefore concluded that, organizational performance is dependent upon the performance of the individuals that make up the organization in terms of the salary increment, retirement benefits and the number of staff employed. That is, organization does not exist in a vacuum; there are people (employees) who make work together towards achieving its goal. Organization exists for a particular goal. The goal cannot be realized except people are trained and developed.

\subsection{Recommendations}

Based on the summary of findings, the following are recommended;

1. The relevant authorities should look into coming up with a financial reporting standard on human resource activities.

2. Organization should enhance the retention of education and training on staff so as to avert wastage of knowledgeable investment.

3. The corporate organizations law should attach information about the value of human resource and the result of their performance during their accounting year in notes and schedule.

4. Finally, it is apposite to suggest that prospective researchers in this area should broaden their study to cover a wider range of human resource Accounting.

\section{References}

[1] Akinsoyinu, A. B. (1992). Human resources accounting: The myth and reality. The Nigerian Accountant, April/June, 18-20.

[2] Abubakar, S. (2006), “An Assessment of Human Resource Accounting Measures and Application Possibilities in Nigeria", Unpublished M. Sc. Accounting and Finance Thesis Submitted to the Postgraduate School, Ahmadu Bello University, Zaria, Nigeria.

[3] Adbullahi, A \& Kirfi, M. M (2012). Human Capital Accounting: Assessing Possibilities for Domestication of Practice in Nigeria. Research Journal of Finance and Accounting, 3(10), 57-63.

[4] American Accounting Association (1973). Report of the committee on accounting for human resources. The Accounting Review, 48(3), 6-11.

[5] American Accounting Association (1974). Statement of basic accounting theory. The Accounting Review Supplement, 40(9), 85-93.

[6] Amir, E., B. Lev. 1996. "Value-relevance of nonfinancial information: The wireless communications industry.." Journal of Accounting and Economics, 22: 3-30.

[7] Boedker, C., Mouristan, J., \& Guthrie, J. (2008). Enhanced business reporting: international trends and possible policy directions. Journal of Human Resource Costing \& Accounting, 12(1), 14. 
[8] Brennan, N. (2001). Reporting intellectual capital in annual reports: Evidence from Ireland. Accounting, Auditing \& Accountability Journal, 14(4), p. 423.

[9] Barney, J. B. (1991). Firm resources and sustained competitive advantage. Journal of Management, 3(17), 99120.

[10] Bowers, David G. (1973). A review of Rensis Likert's Improving the Accuracy of $\mathrm{P} / \mathrm{L}$ Reports and Estimating the Change in Dollar Value of the Human Organization. Michigan Business Review, p. 25.

[11] Bassey, B. E \& Tapang, A. T (2012). Expensed human resources cost and its influence on corporate productivity: A study of selected companies in Nigeria. Global Journal of Management and Business Research, 12(5), 3-8.

[12] Boedker, C., Mouristen, J. \& Guthrie, J. (2008). Enhanced business reporting: International trends and possible policy directions. Journal of Human Resource Cost and Accounting, $12(1), 14$

[13] Becker, B. E. \& Barry, G. (1996). The impact of human resources management on organizational performance: Progress and prospects. Academy of Management Journal, 39 (4), 779-801. Becker, G. S. (1964). Human capital. New York: McGraw Hill

[14] Boedker, C., Mouristan, J. \& Guthrie, J. (2008). Enhanced business reporting: international trends and possible policy directions. Journal of Human Resource Costing \& Accounting, 12(1), 14 -20.

[15] Brummet, R. L. (1970). Accounting for human resource, The Journal of Accountancy, 4(5), 62-66.

[16] Bullen, M. L. (2007). Human resource accounting: A useful tool for measurement and management in organizations. Leadership and Organizational Management Journal, 2(8),85103.

[17] Carper, W. B. (2002). The early development of human resource accounting including them impact of evolving asset valuation theory: A manuscript submitted to ninth world congress of accounting historians, Deak in University Melbourne Australia.

[18] Collins, J. (2001). Good To Great: Why Some Companies Make The Leap, and Others Don't. New York: Harper Business.

[19] Davidove, E. A., \& Schroeder, P. A. (1992). Demonstrating ROI of training. Training and Development, 46(2), 8, 70.

[20] Elias, N. (1970). The impact of accounting for human resources on decision-making: An exploratory study. Unpublished Ph. D. Dissertation, University of Minnesota.

[21] Enofe, A. O., Mgbame, C. Sunday O. S., \& Ovie, O.(2013) Human resources accounting disclosures in Nigeria quoted firms. Research Journal of Finance and Accounting, 4(13), 712.

[22] Flamholtz, E. G. (1979). Towards a psycho-technical systems paradigm of organizational measurement. Decision Sciences, $4(4), 71-84$

[23] Flamholtz, E. G. (1999). Human resource accounting: Advances in concepts (3rd Ed). San Francisco: Jossey-Bass.

[24] Flamholtz, E. G., Bullen, M. L., \& Hua, W. (2002). Human resource accounting: A historical perspective and future implications. Management Decision, 40 (10), 947-54.

[25] Flamholtz, E. G; Bullen, M. L \& Hua, W. (2002). Human resource accounting: A historical perspective and future implications. Management decisions (ABI/INFORM Global). 40(10).

[26] Flamholtz, E. G. (1999). Human resource accounting: Advances, concepts, methods and applications. Boston, MA: Kluwer Academic Publishers.

[27] Flamhotz, E. G. \& Lacey J. M. (1981). Personnel management, human capital theory, and human resource accounting. Los Angeles: Los Angeles University Press.

[28] Frederickson, N. (1986). Toward a broader conception of human intelligence. American Psychology, 41(3),445-452.

[29] Friedman, A. \& Lev, B. (1974). A surrogate measure of the firm's investment in human resources. Journal of Accounting Research,12(4), 235-250.

[30] Glautier, M. W E. (1974), "Human Resource Accounting: A Critique of Research Objectives for the Development of Human Resource Accounting Models", A Paper Presented at a Seminar on Human Resource Accounting held at the European Institute for Advanced Studies in Management, Brussels, November $28-29$.

[31] Gates, S. (2002). Value at work: The risks and opportunities of human measurement and reporting. The Conference Board USA.

[32] Hekimian, J. S. \& Jones, C. (1967). Put people on your balance sheet. Harvard Business Review, 45 (January/February), pp. $107-113$.

[33] Holland, J. (2003). Intellectual capital and the capital marketorganization and competence, Accounting, Auditing and Accountability Journal, 16 (1): 39-48.

[34] Jawahar Lal. (2009). Corporate financial reporting, theory and practice cases. University of Delhi. Taxmann publications, pp 280-302.

[35] Jasrotia, P. (2004), The Need for Human Resource Accounting,http://www.itpeopleindia.com/20021216/cover.sht $\mathrm{ml}$.

[36] Kodwani, A. D. and Tiwari, R. (2007), "Human Resource Accounting - A New Dimension", A Paper Presented at the Canadian Accounting Association (CAAA) Annual Conference, January.

[37] Lau, A. H. and Lau, H. S. (1978), "Some Proposed Approaches for Writing Off Capitalized Human Resource Assets". Journal of Accounting Research, No. 16, pp. 80-102.

[38] Leffingwell, R. J. (2002), Human Relations Accounting Moves Closer to Daily Use. Michigan, USA: EBSCO Publishing.

[39] Lev, B. (2001), Intangibles: Management, Measurement, and Reporting. Washington, D.C.: Brookings Institution Press. Likert, R. (1967). The Human Organisation. New York: McGraw-Hill.

[40] Mustafizur, R., Amzad, H. \& Tabassum, A., (2013). Problem with Human Resource Accounting and A Possible Solution. Research Journal of Finance and Accounting www.iiste.org ISSN 2222-1697 (Paper) ISSN 2222-2847 (Online) Vol.4, No.18, 2013. 
[41] Micah, L. C, Ofurum, C. O, \& Ihendinihu, J. U (2012). Firms Financial Performance and Human Resource Accounting Disclosure in Nigeria. International Journal of Business and Management; 7(14), 67-75.

[42] Okpala, P. O \& Chidi O. C (2010). Human Capital Accounting and its Relevance to Stock Investment Decisions in Nigeria. European Journal of Economics, Finance and Administrative Sciences (21). retrieved 23rd January, 2013 from http://www.eurojournals.com.

[43] Ojha, S. (2013). Prevailing practices of human resource accounting: a case study of IT Industries in India. Journal of Business and Economics, 4(12), 1291-1297.

[44] Pandey, N. (2014). Human resource accounting: The concept and its practice in India. Journal of Management and Technology, 10(1), 29 -38.
[45] Pike, S., Rylander, A. and Roos, G. (2000). Intellectual capital management and disclosure, intellectual capital_Mgt_\&_Discsloure.pdf.

[46] Roslender, R. and Fincham, R. (2001), "Thinking critically about Intellectual Capital Accounting". Accounting, Auditing \& Accountability Journal, Vol. 14, No. 4, pp. 383-399.

[47] Sveiby, K. E. (1997). The new organizational wealth. San Francisco: Berrett-Koehler.

[48] Syed, A. M (2009). Human resource accounting disclosure of Bangladeshi companies and its association with corporate characteristics. BRAC University Journal,.(1)1, 35-43.

[49] Starovic, D., \& Marr, B. (2003). Understanding corporate value: Managing and reporting intellectual capital. London: Chartered Institute of Management Accountants. 